\title{
BALD EAGLE PREDATION ON INLAND DOUBLE-CRESTED CORMORANT
}

\author{
J. DAVID HUNT, ROGER M. EVANS, and GEORGE SHNIER, Zoology
}

Department, University of Manitoba, Winnipeg, Manitoba. R3T 2N2

On 29 May 1991 at 10:15 a.m., while conducting research at Kaweenakumik Lake (approximately $60 \mathrm{~km}$ south of Grand Rapids, Manitoba, and part of the Manitoba Ecological Reserves Program), we observed both a colony of Doublecrested Cormorants and an adjacent colony of Ring-billed Gulls suddenly take to the air above their island nesting site. We knew of no mammalian predators inhabiting the island, so we quickly scanned the area searching for an avian predator. Nothing was sighted, and after approximately two minutes the Ringbilled Gulls returned to their colony. The Double-crested Cormorants however either settled in the lake just off the southern shore of the island, or continued to circle in the air above.

At 10:25 a.m. there were still no cormorants on the island. There was, however, an unusually large number of Ring-billed Gulls dispersed throughout the cormorants' breeding area. Because Ring-billed Gulls are opportunistic feeders, and we have seen them feed on exposed cormorant eggs (pers. obs.), we decided to investigate the cause of the cormorants' continued absence from the nesting area during this critical point in their reproductive cycle. ${ }^{\prime}$
When we arrived on the island at $10: 45 \mathrm{a}$. m., the cormorants were still circling in the air or resting on the lake, while the gulls could be seen pecking at cormorant nest contents. As we moved to approximately $70 \mathrm{~m}$ from the edge of the rocky nesting site, an adult Bald Eagle flew up from the middle of the colony. Upon investigation we found a freshly killed adult cormorant, which the eagle was presumably in the process of consuming. Although the head, esophagus and much of the small intestine remained intact, little else of the bird's internal structure remained. As a result, we were unable to sex the bird.

A quick scan of the colony revealed that a number of cormorant eggs had been destroyed by the gulls, so we lightly covered the remaining eggs with duff (dirt, feathers, vegetation, etc.) before leaving the colony at 10:55 a.m. We have found that covering the eggs this way helps protect them until the cormorants return to their nests, without any negative consequences to the cormorants or to the eggs themselves. When we left the island (with the carcass), the cormorants immediately returned.

Similar colony departures by the cormorants were noted on 27 May at 10:30 a.m., and on 1 June at 4:00 
p.m., but the eagles were not seen. When the cormorant colony was last visited on 24 June only two nests of more than 200 had any eggs left, both singles. This has been a well established cormorant nesting site since at least 1978 (R. Evans, pers. obs.).

Although it has been noted in several papers that Bald Eagles feed on cormorants in coastal areas, only Hobson et al. have described them feeding on inland Double-crested Cormorants. ${ }^{2,3,4,5}$ They found that such predation was a significant source of chick mortality, but made no mention of predation on the adults themselves. For this reason, we believe this to be the first recorded account of Bald Eagle predation on an inland adult Double-crested Cormorant in North America.

The above observations were made while conducting research funded by a University of Manitoba fellowship (D. Hunt) and an NSERC operating grant (R. Evans).

1. BLOKPOEL, $H$. and G.D. TESSIER. 1986. The Ring-billed Gull in Ontario: a review of a new problem species. Can. Wildl. Serv. Occas. Pap. No. 57. $34 \mathrm{pp}$.

2. CASH, K.J., P.J. AUSTIN-SMITH, D. BANKS, D. HARRIS and D.C. SMITH. 1985. Food remains from Bald Eagle nest sites on Cape Breton Island, Nova Scotia. J. Wildl. Manage. 49: 223-225.

3. HOBSON, K.A., R.W. KNAPTON, and W. LYSACK. 1989. Population, diet and reproductive success of Double-crested Cormorants breeding on Lake Winnipegosis, Manitoba, in 1987. Colonial Waterbirds 12: 191-197.

4. MURIE, O.J. 1940. Food habits of the northern Bald Eagle in the Aleutian Islands, Alaska. Condor 42:198-202.

5. TODD, C.S., L.S. YOUNG, R.B. OWEN JR. and F.J. GRAMLICH. 1982. Food habits of Bald Eagles in Maine. J. Wildl. Manage. 46:636-645.

Any young beginner in academic circles who demonstrates to his colleagues that the members of an accepted species can be divided into two slightly different species gets a very conspicuous good mark against his name. In many cases he even helps along a colleague who, a decade later, will again reduce the two species to one, and get an equally good mark against his. J.W. Krutch, 1952. The Desert Year. William Sloane. 